\title{
The sheep KAP8-2 gene, a new KAP8 family member that is absent in humans
}

\author{
Hua Gong ${ }^{1}$, Huitong Zhou', Jolon M Dyer ${ }^{2}$ and Jon GH Hickford ${ }^{1 *}$
}

\begin{abstract}
The keratin-associated proteins (KAPs) are fundamental components of hair and wool fibres, and are believed to in part be responsible for some of the properties of these fibres. KAPs can be divided into three groups: the high sulphur (HS) KAPs, the ultra-high sulphur (UHS) KAPs and the high glycine-tyrosine (HGT) KAPs. KAP8 is a HGT-KAP family and was believed to be coded for by a single gene in both humans and sheep. However, the recent identification of a KAP8-2 gene in goats led us to investigate whether a KAP8-2 gene exists in sheep.

A BLAST search of the Ovine Genome Assembly v2.0 using the coding sequence of caprine KRTAP8-2 identified a homologous region on sheep chromosome 1 (OAR1:123005473_123005664; $E=\mathrm{e}^{-101}$ ). This region was clustered with a number of previously identified KAP genes including (in order from the centromere) KRTAP11-1, KRTAP7-1, KRTAP8-1, KRTAP6-2, KRTAP6-1, KRTAP13-3 and KRTAP24-1. PCR-SSCP analysis of the notional gene revealed two dissimilar PCR-SSCP banding patterns, representing two DNA sequences. A single nucleotide difference $21 \mathrm{bp}$ upstream of the TATA box was identified. The two sequences did not have great homology with known ovine KRTAP sequences, but high sequence identity was found with KRTAP8-2 from goats and reindeer. These results suggest that sheep possess a KAP8-2 gene and that this gene is polymorphic.

The notional KAP8-2 protein is comprised of 63 amino acid residues and is rich in glycine and tyrosine, but has a low cysteine content. In contrast to other HGT-KAPs, ovine KAP8-2 contains more acidic amino acid residues, and this would likely result in a lower isoelectric point (pl) of 6.3.
\end{abstract}

Keywords: KAP8-2 gene (KRTAP8-2); PCR-SSCP; Sheep; Variation

\section{Introduction}

The keratin-associated proteins (KAPs) are part of the matrix of wool fibres and form a cross-linked network with the keratin intermediate filaments (Powell \& Rogers 1997). They typically possess a high content of either cysteine, or glycine and tyrosine. They can be divided into three broad groups: the high sulphur (HS; $\leq 30 \mathrm{~mol} \%$ cysteine) KAPs, the ultra-high sulphur (UHS; $>30$ mol\% cysteine) KAPs and the high glycine-tyrosine (HGT; 35-60 mol\% glycine and tyrosine) KAPs (Powell \& Rogers 1997).

The HGT-KAPs are largely present in the orthocortex of the wool fibre (Powell \& Rogers 1997) and are expressed, shortly after the expression of the keratin intermediate filaments (Rogers 2006). HGT-KAPs vary considerably in abundance both between and within species,

\footnotetext{
* Correspondence: jon.hickford@lincoln.ac.nz

${ }^{1}$ Gene-Marker Laboratory, Faculty of Agriculture and Life Sciences, Lincoln University, PO Box 84, Lincoln 7647, New Zealand

Full list of author information is available at the end of the article
}

ranging from less than $3 \%$ in human hair and wool from the Lincoln breed of sheep, through to $4-12 \%$ in Merino sheep wool, $18 \%$ in the hair of mice and $30-40 \%$ in echidna quills (Gillespie 1990). HGT-KAPs are present at a much lower level in the felting lustre wool mutant compared to normal wool (Gillespie \& Darskus 1971), and in the felting lustre mutant wool follicles the HGT-KAP genes are down-regulated ( $\mathrm{Li}$ et al. 2009), suggesting HGT-KAPs have some association with wool crimp.

All the known HGT-KAP genes have been mapped to chromosome 1 in sheep (Gong et al. 2012a) and clustered in a region that harbours a QTL for mean fibre diameter in medium wool Merino sheep (Beh et al. 2001). In a Merino half-sib family, this chromosome region has also been suggested to be associated with variation in wool fibre diameter (Parsons et al. 1994).

In sheep there are type I and type II HGT-KAPs in three families: KAP6 (type I), KAP7 (type II) and KAP8 (type II) (Gong et al. 2012a). KAP6 is a multi-gene family and 
currently comprises three genes (Gong et al. 2012a; Fratini et al. 1993), whereas KAP7 and KAP8 are currently thought to be single member 'families', as only one gene from each family has been identified in sheep (Kuczek \& Rogers 1987). The numbers of ovine genes reported in these individual HGT-KAP 'families' match well with those identified in the human genome, with reportedly three functional KAP6 genes, one functional KAP7 gene and one functional KAP8 gene (Rogers et al. 2002). Recently, a new KAP8 gene called KRTAP8-2 was identified in goats (Jin et al. 2011). This suggests that the number of KAP8 genes may vary between species and, given the relatedness of sheep and goats, suggests a second member of KAP8 may exist in sheep.

Here we describe the identification of KRTAP8-2 in sheep and report genetic variation identified using PCRSSCP analysis and DNA sequencing.

\section{Materials and methods}

\section{Sheep and DNA samples}

Two hundred and eight New Zealand (NZ) Romneycross sheep were investigated. The NZ Romney and its crosses are the most common dual-purpose sheep New Zealand and include the Perendale and Coopworth breeds. Samples of blood from these sheep were collected directly onto FTA cards (Whatman BioScience, Middlesex, UK) and DNA for analysis was purified from $1.2 \mathrm{~mm}$ punches from the cards, using a procedure described by Zhou et al. (2006).

\section{Bioinformatic analysis of the ovine genome sequence}

The coding sequence of the caprine KAP8-2 gene (GenBank AY510123) was used to BLAST search the Ovine Genome Assembly v2.0 (www.livestockgenomics. csiro.au/sheep). The sequence that showed the most homology with the caprine sequence was presumed to be the notional ovine KAP8-2 gene.

\section{PCR primers and PCR amplification}

Two PCR primers (5'-taggcagtcagtcatcctg-3' and 5'-ataga gaatatgaagtccacg- $3^{\prime}$ ) were designed based on the sequence homologous to caprine KAPS-2 identified in the Ovine
Genome Assembly v2.0. The primers were synthesized by Integrated DNA Technologies (Coralville, IA, USA).

PCR amplification was undertaken using the purified genomic DNA on one punch of the FTA paper, $0.25 \mu \mathrm{M}$ of each primer, $150 \mu \mathrm{M}$ of each dNTP (Bioline, London, $\mathrm{UK}), 2.5 \mathrm{mM}$ of $\mathrm{Mg}^{2+}, 0.5 \mathrm{U}$ of Taq DNA polymerase (Qiagen, Hilden, Germany) and $1 \times$ reaction buffer supplied in a $20-\mu \mathrm{L}$ reaction. The thermal profile for amplification consisted of $2 \mathrm{~min}$ at $94^{\circ} \mathrm{C}$, followed by 35 cycles of $30 \mathrm{~s}$ at $94^{\circ} \mathrm{C}, 30 \mathrm{~s}$ at $60^{\circ} \mathrm{C}$ and $30 \mathrm{~s}$ at $72^{\circ} \mathrm{C}$, with a final extension of $5 \mathrm{~min}$ at $72^{\circ} \mathrm{C}$. This was done in $\mathrm{S} 1000$ thermal cyclers (Bio-Rad, Hercules, CA, USA).

Amplicons were visualized by electrophoresis in 1\% agarose (Bioline) gels, using $1 \times$ TBE buffer containing $200 \mathrm{ng} / \mathrm{mL}$ of ethidium bromide.

\section{Variant screening and sequencing}

PCR amplicons were subject to SSCP analysis. A $0.7-\mu \mathrm{L}$ aliquot of each amplicon was mixed with $7 \mu \mathrm{L}$ of loading dye (98\% formamide, $10 \mathrm{mM}$ EDTA, $0.025 \%$ bromophenol blue, $0.025 \%$ xylene-cyanol) and after denaturation at $95^{\circ} \mathrm{C}$ for $5 \mathrm{~min}$, the samples were cooled rapidly on wet ice and loaded on $16 \mathrm{~cm} \times 18 \mathrm{~cm}, 14 \%$ acrylamide:bisacrylamide (37.5:1) (Bio-Rad) gels. Electrophoresis was performed using Protean II xi cells (Bio-Rad), at $200 \mathrm{~V}$ for $18 \mathrm{~h}$ at $25^{\circ} \mathrm{C}$ in $0.5 \times \mathrm{TBE}$ buffer. The gels were silver-stained by the method of Byun et al. (2009).

PCR amplicons representing individual SSCP patterns were purified using a MinElute PCR Purification kit (Qiagen) and then directly sequenced in both directions.

\section{Sequence analyses}

DNA sequence analyses were carried out using DNAMAN (version 5.2.10, Lynnon BioSoft, Vaudreuil, Canada) and a BLAST search was undertaken of the NCBI GenBank (www.ncbi.nlm.nih.gov/) databases using the sequences identified, to find homologous sequences.

\section{Results}

A BLAST search of the Ovine Genome Assembly v2.0 using the caprine KRTAP8-2 coding sequence (AY510123)

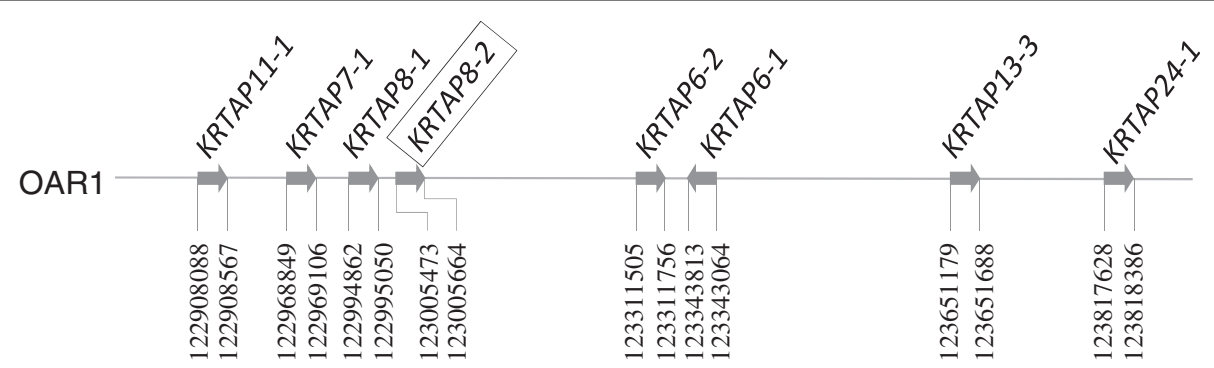

Figure 1 Location of the putative KRTAP8-2 (gene name boxed) together with seven other KRTAPs on sheep chromosome 1. The coding regions of individual KRTAPs are shown, with the nucleotide positions refer to Ovine Genome Assembly v2.0 (www.livestockgenomics. csiro.au/sheep). Arrows represent the direction of transcriptions. 


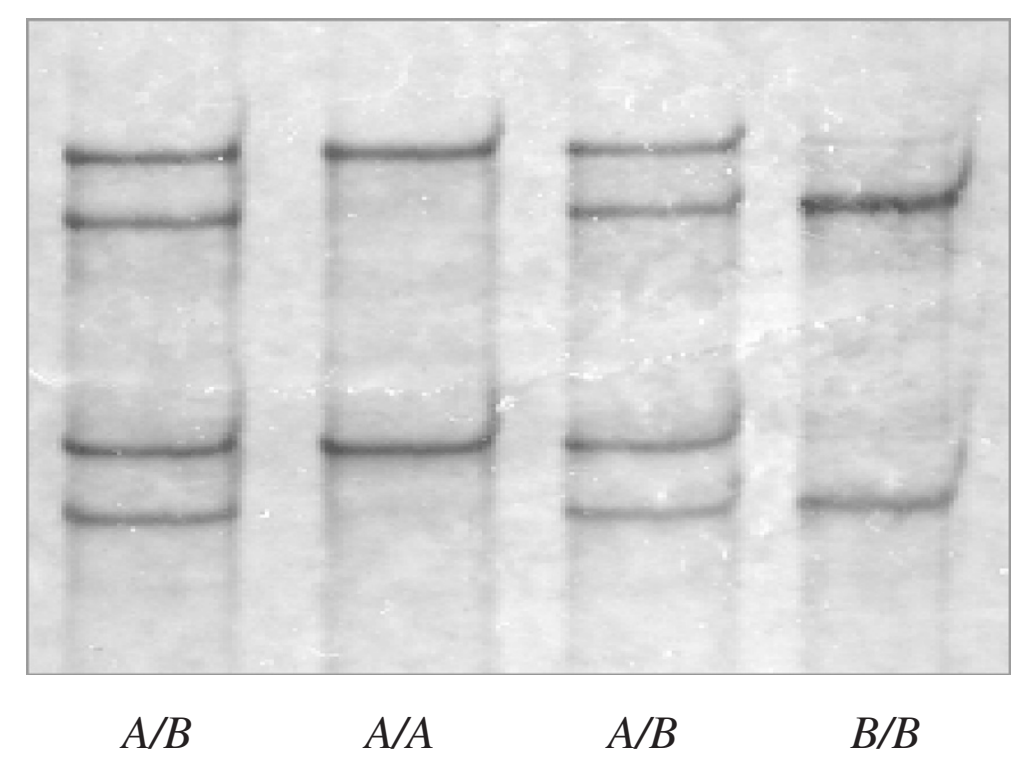

Figure 2 PCR-SSCP of ovine KRTAP8-2. Two unique PCR-SSCP patterns representing two variant sequences are shown.

revealed a region on sheep chromosome 1 (OAR1:1 23005473_123005664; $\left.E=\mathrm{e}^{-101}\right)$ that contained a 192-bp open reading frame and that had 99\% homology with the caprine gene. Near this region, seven previously described ovine KAP genes were also identified and these (including KRTAP8-2) were KRTAP11-1, KRTAP7-1, KRTAP8-1, KRTAP8-2, KRTAP6-2, KRTAP6-1, KRTAP133 and KRTAP24-1(in order from the centromere) (Figure 1). The open reading frame identified had high homology with sheep skin ESTs in GenBank and identical sequences covering the entire open reading frame were found in 44 EST sequences derived from skin tissues (Additional file 1: Table S1).

PCR amplification of the entire open reading frame and its flanking sequence generated amplicons with the expected size of $473 \mathrm{bp}$. SSCP analysis of these amplicons revealed two unique banding patterns, with either one or a combination of two patterns being observed in each sheep (Figure 2).

Sequencing of PCR amplicons revealed that these two PCR-SSCP patterns represented two different DNA sequences. These sequences differed from each other by one nucleotide, $21 \mathrm{bp}$ upstream of the TATA box. Neither of the sequences was identical to the sequence reported in v2.0 of the Ovine Genome Assembly, with three nucleotide differences being detected in the 3' UT region. This likely reflects either additional genetic variation in the gene, or sequencing/assembly errors within v2.0.

The sheep sequences identified here did not share great homology with any other known ovine KRTAP sequence, but sequence similarity was found with the KRTAP8-2 sequences from goats (AY510123) and reindeer (EF407854), with $99 \%$ and $95 \%$ similarity respectively in the coding region. These sequences were assumed to represent allelic variants of ovine KRTAP8-2 and were named variants $A$ and $B$. They were placed in GenBank under the accession numbers KF220646 and KF220646, respectively.

Variant $A$ was found most frequently (at a frequency of $90.5 \%$ ), while variant $B$ was less common (at a frequency of 9.5\%) in the Romney-cross sheep investigated. Three genotypes were observed, with frequencies of $83 \%, 15 \%$ and $2 \%$ for $A A, A B$ and $B B$ respectively.

The putative KRTAP8-2 sequence would encode a 63 amino acid polypeptide, that contained a high level of glycine $(23.8 \mathrm{~mol} \%)$ and tyrosine $(20.6 \mathrm{~mol} \%)$, accounting for $44.4 \mathrm{~mol} \%$ in total of the amino acid content. It had a moderate amount of phenylalanine $(9.5 \mathrm{~mol} \%)$ and serine (7.9 mol\%), but a relatively low cysteine content (3.2 mol\%).

Table 1 Comparison of the amino acid content (mol\%) and pl value of ovine KAP8-2 and other ovine HGT-KAPs

\begin{tabular}{|c|c|c|c|c|c|c|c|c|c|c|}
\hline HGT-KAP & Glycine & Tyrosine & Cysteine & Serine & Phenylalanine & Proline & Aspartic acid & Glutamic acid & pl & Reference \\
\hline KAP6-1 & $37.4-37.5$ & $21.7-23.4$ & $9.4-10.8$ & $14.5-15.6$ & $1.6-2.4$ & 0 & 0 & 0 & $8.1-8.3$ & Gong et al. 2011a \\
\hline KAP6-2 & 38.6 & 21.7 & 12.1 & 10.8 & 2.4 & 1.2 & 0 & 0 & 8.2 & Gong et al. 2011a \\
\hline KAP7-1 & 22.4 & 11.8 & 5.9 & $12.9-14.1$ & 10.6 & 7.1 & 0 & 0 & 8.7 & Gong et al. $2012 c$ \\
\hline KAP8-1 & 22.6 & $16.1-17.7$ & 6.5 & 12.9 & 9.7 & 6.5 & 0 & 0 & 8.3 & Gong et al. 2012c \\
\hline KAP8-2 & 23.8 & 20.6 & 3.2 & 7.9 & 9.5 & 6.4 & 3.2 & 1.6 & 6.3 & This study \\
\hline
\end{tabular}


This polypeptide also possessed $3.2 \mathrm{~mol} \%$ aspartic acid and $1.6 \mathrm{~mol} \%$ glutamic acid, amino acids that are absent in other HGT-KAPs. The calculated isoelectric point (pI) of the protein was 6.3 (Table 1 ).

\section{Discussion}

This study has identified a new gene encoding a HGT-KAP in sheep. The gene was grouped with other KAP genes on ovine chromosome 1, but located at a different position and with a lower sequence similarity to these genes. These suggest that this gene represent a previously un-identified ovine KAP gene. The similarity of this gene sequence to the KRTAP8-2 sequences from goats and reindeer suggests that it is an ovine orthologue of KRTAP8-2.

The putative ovine KRTAP8-2 exhibited sequence variation, with two sequence variants being found. This is consistent with the finding of sequence variation in other ovine KRTAPs (Gong et al. 2012a; Gong et al. 2011a; Gong et al. 2011b; Gong et al. 2012b; Gong et al. 2012c; Zhou et al. 2012). However, in contrast to other KRTAPs, the variation found in ovine KRTAP8-2 was not within the coding region, but instead located near the TATA box. This variation may affect RNA polymerase II binding and hence the expression of the gene, but this would need to be confirmed through further investigation.

The predicted ovine KAP8-2 sequence exhibits some characteristics that are consistent with other type II HGT-KAPs, such as the observed high glycine and tyrosine content and higher levels of phenylalanine, but less cysteine (Table 1). However, some unique features are also observed. Firstly, there is a relatively low cysteine content $(3.2 \mathrm{~mol} \%)$, which contrasts with all previously reported KAPs. Secondly the polypeptide contains a high (4.8 mol\%) aspartic acid and glutamic acid content. These acidic amino acids are not common in other HGT-KAPs. Lastly it is noteworthy that the polypeptide would likely have a low pI (6.3), as a result of this relatively high level of acidic amino acid residues. Such a low pI value has not been observed in any other HGTKAP, where the pI is typically higher than 8 .

Considering there are two types of keratins that crosslink with the KAPs, and of these the type I keratins are characteristically more acidic (pI 4.5-6.0), while the type II keratins tend to be more basic (pI 6.5-8.5) (Bowden et al. 1987); the predicted lower pI value of KAP8-2 may affect its interaction with keratins, and on a charge basis it would be expected to have a greater affinity for the type II (basic) keratins.

While the protein encoded by the ovine KAP8-2 gene has not yet been isolated from wool, the gene appears to be expressed and functional in sheep as many ESTs with sequences identical to this gene have been reported in skin tissues (Additional file 1: Table S1). A functional orthologue of this gene appears to be absent in humans, a species in which only one functional and two pseudogenic KAP genes are found (Rogers et al. 2002). The KAP8-2 gene is the only KAP gene identified and reported to date that is present in sheep and goats, but is absent in humans. The functional significance of this gene in hair and wool characteristics, and in the evolution of hair and wool, awaits further investigation.

\section{Additional file}

Additional file 1: Table S1. Sheep skin ESTs identical to the ovine KAP8-2 gene.

\section{Competing interests}

The authors declare that they have no competing interests.

\section{Authors' contribution}

$H G, H Z$, JMD and JGH designed the experiments. $H G$ and $H Z$ performed the experiments. $\mathrm{HG}, \mathrm{HZ}$ and $\mathrm{JGH}$ analysed data and drafted the manuscript. All authors reviewed and approved the final manuscript.

\section{Acknowledgements}

This work was in part supported by funding from the Foundation for Research Science and Technology (FRST) (C10X0710) and the Lincoln University Gene-Marker Laboratory. Scholarship support for HG was obtained from the Wool Research Organisation of New Zealand Inc. and New Zealand Wool Industry Charitable Trust Postgraduate Scholarship. Q. Fang, S. Byun and W. Yan are thanked for their technical assistance.

\section{Author details}

'Gene-Marker Laboratory, Faculty of Agriculture and Life Sciences, Lincoln University, PO Box 84, Lincoln 7647, New Zealand. 'Lincoln Research Centre, AgResearch Limited, PO Box 8742 Lincoln 8140, New Zealand.

Received: 8 September 2014 Accepted: 9 September 2014

Published: 15 September 2014

\section{References}

Beh KJ, Callaghan MJ, Leish Z, Hulme DJ, Lenane I, Maddox JF (2001) A genome scan for QTL affecting fleece and wool traits in Merino sheep. Wool Tech Sheep Bree 49:88-97

Bowden PE, Stark HJ, Breitkreutz D, Fusenig NE (1987) Expression and modification of keratins during terminal differentiation of mammalian epidermis. Curr Top Dev Bio 22:35-68

Byun SO, Fang Q, Zhou H, Hickford JGH (2009) An effective method for silver-staining DNA in large numbers of polyacrylamide gels. Anal Biochem 385:174-175

Fratini A, Powell BC, Rogers GE (1993) Sequence, expression, and evolutionary conservation of a gene encoding a glycine tyrosine-rich keratin-associated protein of hair. J Biol Chem 268:4511-4518

Gillespie JM (1990) The proteins of hair and other hard a-keratins. In: Goldman RD, Steinert PM (eds) Cellular and Molecular Biology of Intermediate Filaments. Plenum, New York, pp 95-128

Gillespie JM, Darskus RL (1971) Relation between the tyrosine content of various wools and their content of a class of proteins rich in tyrosine and glycine. Aust J Biol Sci 24:1189-1198

Gong H, Zhou H, Hickford JGH (2011a) Diversity of the glycine/tyrosine-rich keratin-associated protein 6 gene (KAP6) family in sheep. Mol Biol Rep 38:31-35

Gong H, Zhou H, Dyer JM, Hickford JGH (2011b) Identification of the ovine KAP11-1 gene (KRTAP11-1) and genetic variation in its coding sequence. Mol Biol Rep 38:5429-5433

Gong H, Zhou H, McKenzie GW, Yu Z, Clerens S, Dyer JM, Plowman JE, Wright MW, Arora R, Bawden CS, Chen Y, Li J, Hickford JGH (2012a) An Updated Nomenclature for Keratin-Associated Proteins (KAPs). Int J Biol Sci 8:258-264 Gong H, Zhou H, Dyer JM, Plowman JE, Hickford JGH (2012b) Identification of the keratin-associated protein 13-3 (KAP13-3) gene in sheep. O J Gen 1:60-64 
Gong H, Zhou H, Plowman JE, Dyer JM, Hickford JGH (2012c) Search for variation in the ovine KAP7-1 and KAP8-1 genes using polymerase chain reaction-singlestranded conformational polymorphism screening. DNA Cell Biol 31:367-370

Jin M, Wang L, Li S, Xing MX, Zhang X (2011) Characterization and expression analysis of KAP7.1, KAP8.2 gene in Liaoning new-breeding cashmere goat hair follicle. Mol Biol Rep 38:3023-3028

Kuczek ES, Rogers GE (1987) Sheep wool (glycine + tyrosine)-rich keratin genes. Eur J Biochem 166:79-85

Li SW, Ouyang HS, Rogers GE, Bawden CS (2009) Characterization of the structural and molecular defects in fibres and follicles of the merino felting lustre mutant. Exp Dermatol 18:134-142

Parsons YM, Piper LR, Cooper DW (1994) Linkage Relationships between Keratin-Associated Protein (KRTAP) Genes and Growth Hormone in Sheep. Genomics 20:500-502

Powell BC, Rogers GE (1997) The role of keratin proteins and their genes in the growth, structure and properties of hair. In: Jolles P, Zahn H, Hocker E (eds) Formation and Structure of Human Hair. Birkhauser Verlag, Basel, Switzerland, pp 59-148

Rogers GE (2006) Biology of the wool follicle: an excursion into a unique tissue interaction system waiting to be re-discovered. Exp Dermatol 15:931-949

Rogers MA, Langbein L, Winter H, Ehmann C, Praetzel S, Schweizer J (2002) Characterization of a first domain of human high glycine-tyrosine and high sulfur keratin-associated protein (KAP) genes on chromosome 21922.1. J Biol Chem 277:48993-49002

Zhou H, Hickford JGH, Fang Q (2006) A two-step procedure for extracting genomic DNA from dried blood spots on filter paper for polymerase chain reaction amplification. Anal Biochem 354:159-161

Zhou H, Gong H, Yan W, Luo Y, Hickford JG (2012) Identification and sequence analysis of the keratin-associated protein 24-1 (KAP24-1) gene homologue in sheep. Gene 511:62-65

doi:10.1186/2193-1801-3-528

Cite this article as: Gong et al:: The sheep KAP8-2 gene, a new KAP8

family member that is absent in humans. SpringerPlus 2014 3:528.

\section{Submit your manuscript to a SpringerOpen ${ }^{\circ}$ journal and benefit from:}

- Convenient online submission

- Rigorous peer review

- Immediate publication on acceptance

- Open access: articles freely available online

- High visibility within the field

- Retaining the copyright to your article

Submit your next manuscript at $\gg$ springeropen.com 